\section{Morte súbita cardíaca na esquizofrenia: o psiquiatra deve estar atento?}

Sudden cardiac death in schizophrenia: should the psychiatrist pay more attention?
Fulvio Alexandre Scorza

Escola Paulista de Medicina (EPM), Universidade Federal de São Paulo (UNIFESP), São Paulo (SP), Brasil Universidade de Mogi das Cruzes (UMC), Mogi das Cruzes (SP), Brasil

Jair de Jesus Mari, Rodrigo Affonseca Bressan Departamento de Psiquiatria, Escola Paulista de Medicina (EPM), Universidade Federal de São Paulo (UNIFESP), São Paulo (SP), Brasil

Financiamento: Inexistente

Conflito de interesses: Inexistente

\section{Referências}

1. Ruschena D, Mullen PE, Burgess P, Cordner SM, Barry-Walsh J, Drummer $\mathrm{OH}$, Palmer S, Browne C, Wallace C. Sudden death in psychiatric patients. Br J Psychiatry. 1998;172:331-6.

2. Glassman AH. Schizophrenia, antipsychotic drugs, and cardiovascular disease. J Clin Psychiatry. 2005;66(Suppl 6):5-10.

3. Zarate CA Jr, Patel J. Sudden cardiac death and antipsychotic drugs: do we know enough? Arch Gen Psychiatry. 2001;58(12):1168-71.

4. Straus SM, Bleumink GS, Dieleman JP, van der Lei J, 't Jong GW, Kingma JH, Sturkenboom MC, Stricker BH. Antipsychotics and the risk of sudden cardiac death. Arch Intern Med. 2004;164(12):1293-7.

5. Casey DE, Haupt DW, Newcomer JW, Henderson DC, Sernyak MJ, Davidson M, Lindenmayer JP, Manoukian SV, Banerji MA, Lebovitz $\mathrm{HE}$, Hennekens $\mathrm{CH}$. Antipsychotic-induced weight gain and metabolic abnormalities: implications for increased mortality in patients with schizophrenia. J Clin Psychiatry. 2004;65(Suppl 7):4-18; quiz: 19-20.

\section{Efficacy of milnacipran in treating anxiety symptoms in schizophrenic patients receiving clozapine: a case series study}

Eficácia do milnaciprano para o tratamento de sintomas ansiosos em pacientes esquizofrênicos medicados com clozapina: uma série de casos olanzapina e clozapina. ${ }^{5}$

Em conclusão geral, a esquizofrenia é uma doença crônica que está associada com um amento da mortalidade. Apesar da morte súbita não ser considerada uma das principais causas de morte em pacientes com esquizofrenia, as alterações autonômicas e suas interações com drogas antipsicóticas devem ser avaliadas com mais atenção pelos clínicos. Como os medicamentos antipsicóticos de $1^{\text {a }}$ e $2^{\mathrm{a}}$ geração podem alterar o ritmo cardíaco e o eletrocardiograma (QT longo e baixa variabilidade da freqüência cardíaca), o médico deve estar atento aos efeitos colaterais desses fármacos, não somente pelo risco de morte súbita, mas pela piora da qualidade de vida que eles acarretam aos pacientes.
Dear Editor,

The prevalence of anxiety disorders in psychotic patients has been found to be from 43 to $45 \% .{ }^{1}$ Such disorders are associated with an increased risk of dependence on, or abuse of, alcohol and other substances, a higher number of suicide attempts and an increased risk of psychotic symptom recurrence. ${ }^{2}$ Anxiety symptoms have a significant negative impact on the quality of life of schizophrenic patients, independently of the presence of depressive symptoms. ${ }^{3-4}$

The benefits of using antidepressants to treat anxiety symptoms have been demonstrated in the individuals with psychosis. ${ }^{3}$ However, the use of antidepressants may worsen the psychotic symptoms. ${ }^{5}$ Although there have been few clinical studies of the 
Table 1 - Gender, age, medications, HAM-A and BPRS scores

\begin{tabular}{|c|c|c|c|c|c|c|c|c|c|c|}
\hline \multirow{2}{*}{ Number } & \multirow{2}{*}{ Gender } & \multirow{2}{*}{$\begin{array}{c}\text { Age } \\
\text { (years) }\end{array}$} & \multirow{2}{*}{$\begin{array}{l}\text { Clozapine daily } \\
\text { dose }\end{array}$} & \multirow{2}{*}{$\begin{array}{l}\text { Milnacipran daily } \\
\text { dose }\end{array}$} & \multicolumn{3}{|c|}{ HAM-A } & \multicolumn{3}{|c|}{ BPRS } \\
\hline & & & & & TO & T4 & T8 & TO & T4 & T8 \\
\hline 1 & Male & 40 & $700 \mathrm{mg}$ & $100 \mathrm{mg}$ & 20 & 13 & 9 & 52 & 42 & 28 \\
\hline 2 & Male & 33 & $900 \mathrm{mg}$ & $150 \mathrm{mg}$ & 33 & 23 & 28 & 78 & 75 & 83 \\
\hline 3 & Male & 30 & $700 \mathrm{mg}$ & $100 \mathrm{mg}$ & 29 & 22 & 25 & 45 & 41 & 46 \\
\hline 4 & Male & 42 & $600 \mathrm{mg}$ & $150 \mathrm{mg}$ & 36 & 34 & 34 & 93 & 91 & 91 \\
\hline 5 & Female & 36 & $700 \mathrm{mg}$ & $150 \mathrm{mg}$ & 38 & 37 & 34 & 80 & 83 & 78 \\
\hline 6 & Female & 29 & $600 \mathrm{mg}$ & $150 \mathrm{mg}$ & 36 & 32 & 38 & 75 & 67 & 70 \\
\hline
\end{tabular}

effects of milnacipran on anxiety, it has been reported to be efficacious in the treatment of depression in patients with schizophrenia spectrum disorders. ${ }^{5}$

Six outpatients (4 males, 2 females) diagnosed with schizophrenia according to the DSM-IV and intense anxiety symptoms, although not meeting the criteria for any DSM-IV anxiety disorder, were studied in order to determine the efficacy of milnacipran in reducing anxiety symptoms in this population. All patients were under treatment with clozapine for refractory schizophrenia.

The mean age of the subjects was $35 \pm 5$ years. The mean daily doses of clozapine and milnacipran were $700 \mathrm{mg}$ and $100 \mathrm{mg}$, respectively. All subjects were submitted to blood workups as recommended for clozapine-treated patients. No hematologic abnormalities were found in this group.

The efficacy of milnacipran in reducing anxiety symptoms, as characterized according to the Hamilton Anxiety Scale (HAMA), which was applied before treatment (TO), after 4 weeks of treatment (T4) and after 8 weeks of treatment (T8). The Brief Psychiatric Rating Scale (BPRS) was also applied at T0, T4 and T8 in order to evaluate possible worsening of schizophrenia symptoms due to treatment with the antidepressant. Comparisons between groups were made using paired Student's $t$-tests. Table 1 shows the demographic data for the patients treated with milnacipran, as well as variations between TO HAM-A and BPRS scores and those obtained at T4 and T8. The mean HAMA scores decreased significantly $(p=0.014)$ from T0 $(32 \pm 7)$ to T4 (27 \pm 9$)$, remaining stable between $\mathrm{T} 4$ and T8 $(28 \pm 10 ; p=0.523)$. From T0 to T8, a trend toward decreasing HAM-A was found ( $p=0.069)$. The mean BPRS score remained virtually unchanged $(p=0.087)$ from TO $(71 \pm 18)$ to T4 $(67 \pm 21)$, from T4 to T8 $(66 \pm 24)(p=0.884)$ and from TO to T8 ( $p=0.326)$. No patient reported adverse effects related to the treatment.

Clearly, the small size of our sample precludes generalization, and studies involving larger samples are needed to confirm these findings. However, our results suggest that milnacipran might be effective in reducing anxiety symptoms in the fourth week of use, and this effect might be maintained until the eighth week of use. In addition, the tolerability profile and the low potential for drug interactions presented by milnacipran could make it a very useful alternative for treating anxiety in patients using clozapine, without the risk of drug interactions and worsening psychotic symptoms.

Clarissa Severino Gama, Vanessa Cassina Zanatto, Felipe Picon, Maria Inês Lobato, Paulo Silva Belmonte-de-Abreu Department of Psychiatry, Hospital de Clínicas de Porto Alegre (HCPA), Universidade Federal do Rio Grande do Sul (UFRGS), Porto Alegre (RS), Brazil
References

1. Cosoff SJ, Hafner RJ. The prevalence of comorbid anxiety in schizophrenia, schizoaffective disorder and bipolar disorder. Aust N Z J Psychiatry. 1998;32(1)67-72.

2. Pallanti S, Quercioli L, Hollander E. Social anxiety in outpatients with schizophrenia: a relevant cause of disability. Am J Psychiatry. 2004;161(1):53-8.

3. Wetherell JL, Palmer BW, Thorp SR, Patterson TL, Golshan S, Jeste DV. Anxiety symptoms and quality of life in middle-aged and older outpatients with schizophrenia and schizoaffective disorder. J Clin Psychiatr. 2003;64(12):1476-82.

4. Braga RJ, Mendlowicz MV, Marrocos RP, Figueira IL. Anxiety disorders in outpatients with schizophrenia: prevalence and impact on the subjective quality of life. J Psychiatr Res. 2005;39(4):409-14

5. Nakanishi S, Kunugi H, Takahashi T. Efficacy of milnacipran for depressive symptoms in schizophrenia spectrum disorders. Psychiatr Clin Neurosci. 2004;58(2):226-7.

\section{Autopercepção da comunicação oral no tratamento de adolescentes usuários de drogas}

\section{Oral communication self-perception in drugis}

users adolescents

\section{Sr. Editor,}

É por meio da comunicação, independente de sua modalidade, que o ser humano expressa conhecimentos, emoções, intenções, desejos e insatisfações. A comunicação oral, a mais utilizada nas relações pessoais, é efetiva quando uma série de habilidades é estabelecida entre locutor e interlocutor: saber ouvir, compartilhar um mesmo código lingüístico e ter discernimento sobre o que, onde e como falar, entre outros.

Apesar de o uso de drogas alterar a comunicação oral e a relação do usuário com o seu meio, raros são os estudos que enfocam essa questão. ${ }^{1-3} \mathrm{O}$ usuário parece não processar o que ouve e tampouco tem consciência de como e o que fala, talvez porque seus interesses centram-se na droga. As intenções implicadas em sua comunicação passam a ter caráter duvidoso e as vontades são, na maioria das vezes, ignoradas. O usuário, por viver em um círculo social restrito, passa a se comunicar de forma peculiar, similar à de outros usuários e essa comunicação é relativamente efetiva, apenas e somente nesse meio.

Com o intuito de pesquisar como se processa a comunicação oral de adolescentes usuários de drogas e os diversos sentidos da mesma, 31 adolescentes de ambos os sexos, do Ambulatório de Adolescentes e Drogas do Serviço de Infância e Adolescência do Instituto de Psiquiatria do Hospital das Clínicas da Faculdade de Medicina da Universidade de São Paulo (CAPPesq 636/03) foram encaminhados por seus psiquiatras ao fonoaudiólogo, que solicitou aos mesmos que tentassem narrar fatos ocorridos na infância e os mais recentes relacionados do cotidiano. As narra- 